\title{
Circulating heat shock protein 27 as a novel marker of subclinical atherosclerosis in type 2 diabetes: a cross-sectional community-based study
}

\section{Xinru Wang}

Huashan Hospital Fudan University

Jie Shi

Shanghai Jiaotong University School of Medicine Xinhua Hospital

Bin Lu

Huashan Hospital Fudan University

Weiwei Zhang

Shanghai Jiaotong University School of Medicine Xinhua Hospital

\section{Yehong Yang}

Huashan Hospital Fudan University

Jie Wen

Huashan Hospital Fudan University

\section{Renming Hu}

Huashan Hospital Fudan University

\section{Zhen Yang}

Shanghai Jiaotong University School of Medicine Xinhua Hospital

Xuanchun Wang ( $\nabla$ xuanchunwangfd@126.com )

Huashan Hospital Fudan University https://orcid.org/0000-0003-2749-8497

\section{Research article}

Keywords: HSP27, carotid intima-media thickness, subclinical atherosclerosis, type 2 diabetes

Posted Date: March 18th, 2020

DOI: https://doi.org/10.21203/rs.2.21171/v2

License: (c) (1) This work is licensed under a Creative Commons Attribution 4.0 International License. Read Full License

Version of Record: A version of this preprint was published at BMC Cardiovascular Disorders on April 25th, 2020. See the published version at https://doi.org/10.1186/s12872-020-01456-7. 


\section{Abstract}

Background Heat shock protein 27 (HSP27) has been proposed as a vital protective factor in atherosclerosis. The objective of the present study was to evaluate the association between circulating HSP27 and intima-media thickness (IMT) of the common carotid artery in individuals with type 2 diabetes and to determine whether HSP27 represents an independent marker for subclinical atherosclerosis in this patient population.

Methods We performed a cross-sectional community-based study consisting in 186 Chinese subjects with a median duration of diabetes of 8.2 years who underwent carotid ultrasound IMT measurement. Serum HSP27 levels were assessed by ELISA.

Results Serum HSP27 levels were significantly higher in the IMT $(+,>1.0 \mathrm{~mm})$ group than in the IMT (-, $\leq 1.0 \mathrm{~mm}$ ) group, with the median value of $8.80 \mathrm{ng} / \mathrm{mL}(5.62-12.25)$ and $6.93 \mathrm{ng} / \mathrm{mL}(4.23-9.60)$, respectively ( $P=0.006)$. The discriminative value of HSP27 to evaluate IMT was $7.16 \mathrm{ng} / \mathrm{mL}$ and the area under the curve was $0.72(95 \% \mathrm{Cl}=0.64-0.80, \mathrm{P}=0.0065)$. Spearman's rank correlation analysis demonstrated that the concentrations of circulating HSP27 were positively correlated with carotid IMT ( $r$ $=0.198, P=0.007)$ and blood urea nitrogen $(r=0.170, P<0.05)$. Furthermore, in the logistic model, serum HSP27 levels were found to be independent predictors of carotid IMT in type 2 diabetic patients after adjustment for onset age of diabetes, blood pressure, total cholesterol and C-reactive protein. $(\mathrm{OR}=1.085$, $\mathrm{P}=0.022)$.

Conclusions Circulating HSP27 level positively correlates with carotid IMT, is an independent predictor for early atherosclerotic changes in diabetes, and may represent a novel marker of subclinical atherosclerosis in type 2 diabetes.

\section{Background}

Atherosclerotic cardiovascular disease (CVD) is the dominating cause of increasing mortality among patients with type 2 diabetes. Increasing carotid intima-media thickness (IMT), closely associated with CVD, is generally accepted as a surrogate marker for atherosclerosis[1-3].

Heat shock protein 27 (HSP27), also termed HSPB1[4], is a ubiquitously expressed member of the small heat shock protein family[5]. Originally identified as a intracellular molecular chaperone, HSP27 facilitates the correct folding of proteins[6]. In recent years, the extracellular effects of HSP27 on the cardiovascular system have indicated a protective effect against atherosclerosis[7]. Clinical studies have reported that serum HSP27 levels were dramatically decreased in patients with carotid atherosclerosis compared with healthy controls[8]. Low circulating HSP27 levels were found to be associated with high risk of coronary artery disease[9]. Furthermore, reduced HSP27 levels were observed in unstable plaques versus stable plaques[10]. 
Although these studies have implicated certain roles of HSP27 in atherosclerosis or coronary heart disease (CHD), little is known about the direct relationship between serum HSP27 concentration and subclinical arthrosclerosis in the context of type 2 diabetes. In the present study, we examined whether circulating HSP27 levels were associated with carotid IMT in patients with type 2 diabetes to determine whether HSP27 may represent a potential predictor of early-stage atherosclerosis in this patient population.

\section{Methods}

\section{Participants and study design}

This trial was designed as a cross-sectional study. Participants were recruited in Shanghai from February 2004 to July 2004 . Twenty residential areas administered by 20 residents' committees were sampled randomly in the central area of Shanghai. Questionnaires administered by endocrinologists and primary care clinicians were used to identify individuals with type 2 diabetes. Two hundred individuals were randomly selected, and 186 of these individuals for whom complete information was available were enrolled in our study[11]. Based on carotid IMT values detected by color ultrasound, subjects were stratified into an IMT $(-)$ group $(n=110)$ or an IMT $(+)$ group $(n=76)$. The IMT $(-)$ group included patients with carotid IMT levels $\leq 1.0 \mathrm{~mm}$ while the IMT $(+)$ group contained patients with IMT values $>1.0 \mathrm{~mm}$. All subjects provided written informed consent prior to participation. The research protocol was approved by the Institutional Review Board of Huashan Hospital, Fudan University School of Medicine.

\section{Anthropometric parameters and biochemical indexes}

The subjects' detailed histories were obtained using questionnaires. Physical examination and anthropometric measurements were performed by trained physicians. Waist circumference (WC) was measured at the midpoint between the lower margin of the least palpable rib and the top of the iliac crest in the late exhalation phase in a standing position. Hip circumference was measured around the widest portion of the buttocks using a tape parallel to the floor. Blood pressure measurement was obtained using a standard manual mercury sphygmomanometer at a steady state on the upper arm. Venous blood samples were collected between 7:00 and 8:00 AM from the antecubital vein of each subject after overnight fasting. Blood glucose, serum insulin, total cholesterol (TC), triglycerides (TG), high-density lipoprotein cholesterol (HDL-C), low-density lipoprotein cholesterol (LDL-C), blood urea nitrogen (BUN), and serum creatinine (Scr) were determined using standard methods in a qualified laboratory using a Hitachi 7080 analyzer (Hitachi, Ltd., Tokyo, Japan). C-reactive protein (CRP) was measured in duplicate by ELISA using a Duoset kit (DY1707, R\&D Systems, Minneapolis, MN). Glycated hemoglobin A1c (HbA1c) was assessed by high-pressure liquid chromatography (HLC-723G7; Tosoh, Shanghai, China). The homeostasis model assessment of insulin resistance (HOMA-IR) was calculated based on the formula of Matthews at al.[12]. The MDRD Study equation was used for the calculation of estimated glomerular filtration rate (eGFR)[13]. 
Type 2 diabetes was defined as the presence of $\geq 1$ of the following criteria: fasting plasma glucose $\geq 7.0 \mathrm{mmol} / \mathrm{L}$; plasma glucose $\geq 11.1 \mathrm{mmol} / \mathrm{L} 2$ hours after a $75-\mathrm{g}$ oral glucose load as in a glucose tolerance test (OGTT); and symptoms of high blood sugar and casual plasma glucose $\geq 11.1 \mathrm{mmol} / \mathrm{L}$. CVD was defined as stroke and CHD, including unstable or stable angina and myocardial infarction, while lipid-lowering drugs referred to statins or fibrates.

\section{Measurement of serum HSP27}

Serum HSP27 levels were measured in duplicate using a commercial enzyme-linked immunosorbent assay kit (QIA119, Calbiochem, San Diego, CA) according to the manufacturer's instructions. The intraand inter-assay coefficients of variation of the ELISA were $6.2 \%$ and $8.3 \%$, respectively.

\section{Measurement of carotid IMT}

With the reference to the European Mannheim carotid IMT consensus, the intima-media thickness of the common carotid arteries of all subjects was measured using an Acuson Sequoia 512 system (Siemens Medical Solutions USA, Mountain View, CA). The procedure was performed in subjects in a supine position by an experienced ultra-sonographer who was unaware of the subjects' demographic and clinical characteristics. Three arterial sites were evaluated: the bilateral distal common carotid arteries, the carotid bulbs, and the proximal internal carotid arteries. Different scanning angles (anterior, lateral, posterior) were used to identify the thickest IMT in each wall. Both left and right carotid IMTs were assessed, and three measurements were performed for each subject. The mean values of the maximum IMT in both the left and right sides of the common carotid arteries were defined as carotid artery IMT.

\section{Statistical analysis}

Quantitative data were evaluated using the Kolmogorov-Smirnov test to determine whether they followed a normal distribution. Parameters were considered normally distributed if $P>0.05$. Normally distributed data were reported as means and standard deviations, while variables with a skewed distribution were expressed as medians (interquartile range). Categorical variables were presented as frequencies and percentages. One-way ANOVA and a Chi-squared test were used for comparisons between two groups. Spearman's correlation was used to evaluate the correlation between serum HSP27 concentration and other clinical indexes. Receiver operating characteristics (ROC) curve analysis was performed to calculate the area under the curve (AUC) and the cutoff value of HSP27 for IMT. The determinants of carotid IMT were explored using univariate and multivariate logistic analysis. Linear regression analysis was also used. Variables with statistically significant correlations $(P<0.05)$ in univariate analysis were examined in the multivariate model. All statistical analyses were conducted using the SPSS version 25 (IBM Corp., 
Armonk, NY) and Prism 8 software (GraphPad, San Diego, CA). Two-sided values of $P<0.05$ were considered statistically significant.

\section{Results}

\section{Subject characteristics}

The characteristics of the 186 subjects and the two subgroups divided according to carotid IMT $(1.0 \mathrm{~mm})$ are shown in Table 1. The low median HbA1c (6.70\%) and normal eGFR $\left(121.15 \pm 30.98 \mathrm{~mL} \cdot \mathrm{min}^{-1} 1.73 \mathrm{~m}^{-}\right.$

$\left.{ }^{2}\right)$ values were indicative of generally well-controlled type 2 diabetes among the study subjects. The mean IMT levels in the IMT (-) and IMT (+) groups were $0.78 \mathrm{~mm}$ and $1.41 \mathrm{~mm}$, respectively. Compared with the IMT (-) individuals, the IMT (+) group was 6 years older $(P<0.001)$ and had a higher onset age of diabetes $(P<0.01)$. The levels of systolic blood pressure (SBP) $(P<0.05)$, diastolic blood pressure (DBP) $(P<0.05)$, TC $(P<0.05)$, and CRP $(P<0.05)$ were significantly higher in the IMT $(+)$ group than in the IMT $(-)$ group. There was no statistical difference in sex, smoking status, alcohol consumption, use of lipid-lowering drugs, history of CVD, duration of type 2 diabetes, BMI, WC, WHR, FBG, PBG, fasting insulin, fasting $C$ peptide, 2 $\mathrm{h}$ insulin, $2 \mathrm{~h}$ C peptide, HOMA-IR, HbA1c, BUN, Scr, serum uric acid, eGFR, TG, LDL-C, HDL-C between the two groups (all $P>0.05$, Table 1 ).

\section{Difference in serum HSP27 between the two groups}

The median value of serum HSP27 in the study population was $7.85 \mathrm{ng} / \mathrm{mL}$ (IQR: $4.78-10.92$, Figure 1). As shown in Figure 2, the median serum HSP27 level in the IMT (+) group was $8.80 \mathrm{ng} / \mathrm{mL}$ (IQR: 5.6212.25 , Table 1), significantly higher than that in the IMT (-) group (6.93 ng/mL, IQR: $4.23-9.60, P=0.006)$.

\section{Association between serum HSP27 level and carotid IMT}

Logistic regression analysis was used to identify independent determinants of carotid IMT and to estimate odds ratios and $95 \% \mathrm{Cl}$. Seven factors were identified as significant predictors using univariate analysis, including age, onset age of diabetes, SBP, DBP, TC, CRP, and HSP27 (all $P<0.05$, Table 2). In the multivariate model, these factors were defined as covariates, while carotid IMT ( $\leq 1.0 \mathrm{~mm}$ or $>1.0 \mathrm{~mm}$ ) was introduced as a dependent variable. The results illustrated that after adjusting for onset age of diabetes, SBP, DBP, TC and CRP, age, and HSP27 were still independently associated with carotid IMT in type 2 diabetes, with adjusted odds ratios of $1.061(P=0.028)$ and $1.085(P=0.022)$, respectively (Table 3). Moreover, a positive relationship between HSP27 and carotid IMT ( $\beta=0.019, P=0.002)$ was observed in the multiple linear regression model (Supplemental Table 1 and Table 2). Age $(\beta=0.190, P=0.007)$ and TC $(\beta=0.081, P=0.001)$ independently correlated with carotid IMT in multiple linear regression analysis. 


\section{ROC curve analysis}

ROC curve analysis was applied to identify an optimal cutoff value for HSP27 to discriminate between $>1$ and $<1$ IMT (Figure 3 ). The AUC of the ROC curve for predicting IMT was 0.72 (95\%Cl=0.64-0.80, $P=0.0065)$ and the optimal cutoff value of HSP27 was $7.16 \mathrm{ng} / \mathrm{mL}$ with sensitivity of $75.05 \%(95 \% \mathrm{Cl}$ $=64.04-84.04)$ and low specificity of $67.73 \%(95 \% \mathrm{Cl}=58.46-76.81)$.

\section{Correlations between serum HSP27 and other clinical parameters}

As presented in Table 4, serum HSP27 levels of the subjects correlated positively with BUN $(r=0.170$, $P<0.05)$ and carotid IMT $(r=0.198, P=0.007)$, whereas the relationships between HSP27 and other clinical parameters were not significant.

\section{Discussion}

The major findings of this study were that the median HSP27 level in the IMT (+) group was significantly higher than that in the IMT (-) group, and serum HSP27 level was positively correlated with carotid IMT $(r=0.198, P=0.007)$. Our finding that serum HSP27 concentrations were positively associated with BUN but not with other clinical parameters is in alignment with that of a previous study in which HSP27 was found to be related to serum creatinine level[14]. Furthermore, we identified that HSP27 was an independent predictor of subclinical atherosclerosis in patients with type 2 diabetes, even after adjusting for several clinical factors. The lack of circulating biomarkers for early stage atherosclerosis in diabetes requires further clinical investigation. Therefore, our findings may support the diagnostic value of elevated circulating HSP27.

HSP27 acts as an antioxidant with the ability to reduce the levels of reactive oxygen species (ROS) through increased intracellular glutathione and decreased intracellular iron[15], which indicates a potential atheroprotective role of HSP27 in atherosclerosis. Another mechanism by which HSP27 exerts its protective function may be attributed to its binding to and/or reducing scavenger receptor-A (SR-A), thus leading to the prevention of acetylated low-density lipoprotein (acLDL) uptake and attenuation of foam cell formation[16]. HSP27 may also reduce the cholesterol content in plaques by more than $30 \%$ [17]. In apolipoprotein E null ( $\mathrm{ApoE}^{-/-}$) mice, which are prone to atherosclerosis, extracellular HSP27 activated the NF-KB signaling pathway to induce increased expression of granulocyte-monocyte colonystimulating factor (GM-CSF), ATP-binding cassette transporter A1 (ABCA1), and ATP-binding cassette transporter G1 (ABCG1), thus facilitating cholesterol efflux [17]. In addition, overexpression of HSP27 in this mouse model contributed to a reduction in lesion formation and plaque stability[9.16.18]. Stimulation of the release of anti-inflammatory IL-10 via the p38 signaling pathway may also contribute to this effect[19]. 
An immediate responses to stress, inflammation, and cellular damage is to secrete HSP27 into the blood to protect the body[20]. Given the protective role of HSP27 in protecting vessels from oxidative stress[21] and inhibiting inflammation[22], the higher levels of serum HSP27 observed in the IMT (+) group compared with the IMT (-) group in our study may represent a consequence of a compensatory response to inflammation and oxidative stress in the early stage of atherosclerosis. HSP27 may have been induced to counteract these unfavorable factors in the initiation of atherosclerosis. Similarly, Park et al. reported that circulating HSP27 levels in acute coronary syndrome (ACS) patients were remarkably higher than those in an age- and sex-matched healthy control group[23]. Compared with controls, a significant increase in serum HSP27 in patients with CHD was also observed in a recent study[24].

Contrary to these results, circulating HSP27 levels were reported as decreased $>70 \%$ in patients with carotid stenosis[8] and coronary artery diseases (CAD) compared with healthy subjects[25]. In addition to reduced concentrations of HSP27, patients with CAD in these two studies had more severe comorbidities compared to patients with higher HSP27 level in Park's and Zhang HL's studies [23,24], including diabetes and hypertension in both studies and smoking in the former plus hyperlipemia in the latter. Patients in these two studies had serum HSP27 levels even decreased to a mean value of $0.19 \mathrm{ng} / \mathrm{mL}$ and $1.23 \mathrm{ng} / \mathrm{mL}$, respectively. Therefore, we speculated that the patients in the two studies was too severe to secret HSP27 to compensate for inflammation and oxidative stress under the complicated situations. The degradation of extracellular HSP27 by proteases such as upregulated plasmin in plaque[26] and matrix metalloproteases (MMPs) [27, 28] may also have accounted for the decline in serum HSP27. In the progression of arthrosclerosis, the degradation of extracellular HSP27 by proteases such as upregulated plasmin in plaques [24], matrix metalloproteases (MMPs) [49,50] accounted for the subsequent decline of serum HSP27.

Our study had several limitations. First, this cross-sectional study was confined to a specific time point and was therefore unable to identify cause-effect relationships. Whether HSP27 was an independent marker of future cardiovascular events remained to be explored, given the lack of follow-up data. Second, our study included a small number of subjects. Finally, although we have identified a relationship between circulating HSP27 and carotid IMT in type 2 diabetes, the underlying mechanisms of the direct role of HSP27 remains unclear.

\section{Conclusions}

Our study findings demonstrate a positive correlation between circulating HSP27 and carotid IMT, indicating that serum HSP27 may represent a novel biomarker for the progression and diagnosis of subclinical atherosclerosis in type 2 diabetes.

\section{Abbreviations}

intima-media thickness (IMT), cardiovascular disease (CVD), body mass index (BMI), waist circumference (WC), waist-hip ratio (WHR), systolic blood pressure (SBP), diastolic blood pressure (DBP), 
fasting blood glucose (FBG), postprandial blood glucose (PBG), homeostatic model assessment of insulin resistance (HOMA-IR), glycated hemoglobin A1c (HbA1c), blood urea nitrogen (BUN), serum creatinine (Scr), estimated glomerular filtration rate (eGFR), total cholesterol (TC), triglycerides (TG), low density lipoprotein-cholesterol (LDL-C), high density lipoprotein-cholesterol (HDL-C), C-reactive protein (CRP), urine albumin-to-creatinine ratio (UACR), odds ratio (OR), confidence interval (Cl)

\section{Declarations}

\section{Ethics approval and consent to participate}

The research protocol was approved by the Institutional Review Board of Huashan Hospital, Fudan University School of Medicine. All subjects provided written informed consent prior to participation.

\section{Consent for publication}

Not applicable

\section{Availability of data and materials}

Datasets are available from the corresponding author upon reasonable request.

\section{Competing interests}

The authors declare that they have no competing interests.

\section{Funding}

The National Natural Science Foundation of China (grant numbers 81370953, 81370936 and 81873645 ) supported the design of the study and data collection.

The Science and Technology Commission of Shanghai Municipality (grant numbers 16140901200, 18140902100 and 16PJ1401700) supported data analysis and manuscript writing.

\section{Authors' contributions}


XRW, ZY, XCW proposed the idea and designed the study; BL, RH, JS collected and organized the database; XRW, JS contributed to the statistical analysis and the interpretation of the data; ZY, XCW, WZ, JW and YY supervised the project administration; XRW wrote the first draft of the paper; $Z Y, X C W$ revised the article. All authors commented on the results and read the final manuscript.

\section{Acknowledgements}

We would like to thank all of the study participants of Department of Endocrinology of Huashan Hospital and Xinhua Hospital.

\section{References}

[1] Cardoso CRL, Salles GC, Leite NC, Salles GF: Prognostic impact of carotid intima-media thickness and carotid plaques on the development of micro- and macrovascular complications in individuals with type 2 diabetes: the Rio de Janeiro type 2 diabetes cohort study. Cardiovasc Diabetol 2019, 18(1):2.

[2] Centurion OA: Carotid Intima-Media Thickness as a Cardiovascular Risk Factor and Imaging Pathway of Atherosclerosis. Crit Pathw Cardiol 2016, 15(4):152-160.

[3] Stein JH, Korcarz CE, Hurst RT, Lonn E, Kendall CB, Mohler ER, Najjar SS, Rembold CM, Post WS: Use of carotid ultrasound to identify subclinical vascular disease and evaluate cardiovascular disease risk: a consensus statement from the American Society of Echocardiography Carotid Intima-Media Thickness Task Force. Endorsed by the Society for Vascular Medicine. J Am Soc Echocardiogr 2008, 21(2):93-111; quiz 189-190.

[4] Van Montfort R, Slingsby C, Vierling E: Structure and function of the small heat shock protein/alphacrystallin family of molecular chaperones. Adv Protein Chem 2001, 59:105-156.

[5] Beck FX, Neuhofer W, Muller E: Molecular chaperones in the kidney: distribution, putative roles, and regulation. Am J Physiol Renal Physiol 2000, 279(2):F203-215.

[6] Ranford JC, Henderson B: Chaperonins in disease: mechanisms, models, and treatments. Mol Pathol 2002, 55(4):209-213.

[7] Batulan Z, Pulakazhi Venu VK, Li Y, Koumbadinga G, Alvarez-Olmedo DG, Shi C, O'Brien ER: Extracellular Release and Signaling by Heat Shock Protein 27: Role in Modifying Vascular Inflammation. Front Immunol 2016, 7:285.

[8] Martin-Ventura JL, Duran MC, Blanco-Colio LM, Meilhac O, Leclercq A, Michel JB, Jensen ON, Hernandez-Merida S, Tunon J, Vivanco F et al: Identification by a differential proteomic approach of heat shock protein 27 as a potential marker of atherosclerosis. Circulation 2004, 110(15):2216-2219. 
[9] Seibert TA, Hibbert B, Chen YX, Rayner K, Simard T, Hu T, Cuerrier CM, Zhao X, de Belleroche J, Chow BJ et al: Serum heat shock protein 27 levels represent a potential therapeutic target for atherosclerosis: observations from a human cohort and treatment of female mice. J Am Coll Cardio/ 2013, 62(16):14461454.

[10] Lepedda AJ, Cigliano A, Cherchi GM, Spirito R, Maggioni M, Carta F, Turrini F, Edelstein C, Scanu AM, Formato M: A proteomic approach to differentiate histologically classified stable and unstable plaques from human carotid arteries. Atherosclerosis 2009, 203(1):112-118.

[11] Lu B, Yang Y, Yang Z, Feng X, Wang X, Zhang Z, Hu R: Insulin resistance in Chinese patients with type 2 diabetes is associated with C-reactive protein independent of abdominal obesity. Cardiovasc Diabetol 2010, 9:92.

[12] Matthews DR, Hosker JP, Rudenski AS, Naylor BA, Treacher DF, Turner RC: Homeostasis model assessment: insulin resistance and beta-cell function from fasting plasma glucose and insulin concentrations in man. Diabetologia 1985, 28(7):412-419.

[13] K/DOQI clinical practice guidelines for chronic kidney disease: evaluation, classification, and stratification. Am J Kidney Dis 2002, 39(2 Suppl 1):S1-266.

[14] Jakhotia S, Sivaprasad M, Shalini T, Reddy PY, Viswanath K, Jakhotia K, Sahay R, Sahay M, Reddy GB: Circulating levels of Hsp27 in microvascular complications of diabetes: Prospects as a biomarker of diabetic nephropathy. J Diabetes Complications 2018, 32(2):221-225.

[15] Arrigo AP, Virot S, Chaufour S, Firdaus W, Kretz-Remy C, Diaz-Latoud C: Hsp27 consolidates intracellular redox homeostasis by upholding glutathione in its reduced form and by decreasing iron intracellular levels. Antioxid Redox Signa/ 2005, 7(3-4):414-422.

[16] Rayner K, Chen YX, McNulty M, Simard T, Zhao X, Wells DJ, de Belleroche J, O'Brien ER: Extracellular release of the atheroprotective heat shock protein 27 is mediated by estrogen and competitively inhibits acLDL binding to scavenger receptor-A. Circ Res 2008, 103(2):133-141.

[17] Pulakazhi Venu VK, Adijiang A, Seibert T, Chen YX, Shi C, Batulan Z, O'Brien ER: Heat shock protein 27-derived atheroprotection involves reverse cholesterol transport that is dependent on GM-CSF to maintain ABCA1 and ABCG1 expression in ApoE(-/-) mice. Faseb j 2017, 31(6):2364-2379.

[18] Cuerrier CM, Chen YX, Tremblay D, Rayner K, McNulty M, Zhao X, Kennedy CR, de BelleRoche J, Pelling AE, O'Brien ER: Chronic over-expression of heat shock protein 27 attenuates atherogenesis and enhances plaque remodeling: a combined histological and mechanical assessment of aortic lesions. PLoS One 2013, 8(2):e55867.

[19] De AK, Kodys KM, Yeh BS, Miller-Graziano C: Exaggerated human monocyte IL-10 concomitant to minimal TNF-alpha induction by heat-shock protein 27 (Hsp27) suggests Hsp27 is primarily an 
antiinflammatory stimulus. J Immuno/ 2000, 165(7):3951-3958.

[20] Osterloh A, Breloer M: Heat shock proteins: linking danger and pathogen recognition. Med Microbiol Immuno/2008, 197(1):1-8.

[21] Najemnikova E, Rodgers CD, Locke M: Altered heat stress response following streptozotocin-induced diabetes. Cell Stress Chaperones 2007, 12(4):342-352.

[22] Shi C, Ulke-Lemee A, Deng J, Batulan Z, O'Brien ER: Characterization of heat shock protein 27 in extracellular vesicles: a potential anti-inflammatory therapy. Faseb j 2019, 33(2):1617-1630.

[23] Park HK, Park EC, Bae SW, Park MY, Kim SW, Yoo HS, Tudev M, Ko YH, Choi YH, Kim S et al:

Expression of heat shock protein 27 in human atherosclerotic plaques and increased plasma level of heat shock protein 27 in patients with acute coronary syndrome. Circulation 2006, 114(9):886-893.

[24] Zhang HL, Jia KY, Sun D, Yang M: Protective effect of HSP27 in atherosclerosis and coronary heart disease by inhibiting reactive oxygen species. J Cell Biochem 2019, 120(3):2859-2868.

[25] Jin C, Phillips VL, Williams MJ, van Rij AM, Jones GT: Plasma heat shock protein 27 is associated with coronary artery disease, abdominal aortic aneurysm and peripheral artery disease. Springerplus 2014, 3:635.

[26] Martin-Ventura JL, Nicolas V, Houard X, Blanco-Colio LM, Leclercq A, Egido J, Vranckx R, Michel JB, Meilhac O: Biological significance of decreased HSP27 in human atherosclerosis. Arterioscler Thromb Vasc Biol 2006, 26(6):1337-1343.

[27] Lamfers ML, Grimbergen JM, Aalders MC, Havenga MJ, de Vries MR, Huisman LG, van Hinsbergh VW, Quax PH: Gene transfer of the urokinase-type plasminogen activator receptor-targeted matrix metalloproteinase inhibitor TIMP-1.ATF suppresses neointima formation more efficiently than tissue inhibitor of metalloproteinase-1. Circ Res 2002, 91(10):945-952.

[28] Choi SH, Lee HJ, Jin YB, Jang J, Kang GY, Lee M, Kim CH, Kim J, Yoon SS, Lee YS et al: MMP9 processing of HSPB1 regulates tumor progression. PLoS One 2014, 9(1):e85509.

\section{Tables}


Table 1. General characteristics of study subjects

\begin{tabular}{|c|c|c|c|c|}
\hline Characteristic & Total & IMT (-) & IMT $(+)$ & $\begin{array}{l}P \\
\text { value }\end{array}$ \\
\hline Subjects & 186 & 110 & 76 & \\
\hline Age (years) & $67(57-)$ & $64(53$. & & $0.000^{*}$ \\
\hline Sex (male/female) & $74 / 1$ & & $35 / 41$ & 0.147 \\
\hline Smoking (\%) & 76.88 & & 75.00 & \\
\hline $\begin{array}{l}\text { Alcohol (\%) } \\
\text { lipid-lowering } \quad \text { drugs }\end{array}$ & $\begin{array}{l}8.60 \\
50.98\end{array}$ & $\begin{array}{l}9.09 \\
60.91\end{array}$ & $\begin{array}{l}7.89 \\
51.32\end{array}$ & $\begin{array}{l}0.078 \\
0.194\end{array}$ \\
\hline $\begin{array}{l}(\%) \\
\text { CVD (\%) }\end{array}$ & 2043 & 1727 & 2500 & 0199 \\
\hline Onset age of diabetes & $57.12 \pm 11.16$ & $54.76 \pm 11.29$ & \pm 10.13 & $0.001 *$ \\
\hline Duration of diabetes & $6(3-10)$ & $6(3-10)$ & $7(4-12)$ & 0.370 \\
\hline BMI $\left(\mathrm{kg} / \mathrm{m}^{2}\right)$ & $24.63 \pm 3.21$ & $24.46 \pm 3.19$ & $24.88 \pm 3.23$ & 0.392 \\
\hline WC $(\mathrm{cm})$ & $81.43 \pm 8.76$ & 81.10 & $81.90 \pm 8.81$ & 0.544 \\
\hline WHR & & & & \\
\hline $\mathrm{SBP}(\mathrm{mmHg})$ & $140(130-150)$ & $9.5-150 \square$ & $142(13$ & $0.001 *$ \\
\hline DBP (mmHg) & $84(78-92)$ & $82(7$ & $86(80-94.75)$ & $0.026 *$ \\
\hline FBG $(\mathrm{mmol} / \mathrm{L})$ & $\begin{array}{l}7.80 \\
10.00)\end{array}$ & 7.5 & $\begin{array}{l}8.60 \\
10.10)\end{array}$ & 0.236 \\
\hline $\begin{array}{l}\text { PBG (mmol/L) } \\
\text { Fasting insulin (pmol/L) }\end{array}$ & $\begin{array}{l}15.73 \pm 6.08 \\
12.20 \quad(7.44-\end{array}$ & $\begin{array}{l}15.60 \pm 6.16 \\
12.22\end{array}$ & $\begin{array}{l}15.93 \pm 6.00 \\
12.20 \quad(7.54-\end{array}$ & $\begin{array}{l}0.717 \\
0.387\end{array}$ \\
\hline $2 \mathrm{~h}$ insulin $(\mathrm{pmol} / \mathrm{L})$ & $49 \quad$ (28.06- & $47.46 \quad$ (29.43- & 43.99 (25.77- & 0.780 \\
\hline $\begin{array}{l}\text { Fasting } \\
(\mathrm{ng} / \mathrm{mL})\end{array} \quad \mathrm{C} \quad$ peptide & $(2.22-3.78)$ & $2.96(2.23-3.72)$ & $2.91(2.15-3.86)$ & 0.622 \\
\hline $2 \mathrm{~h}$ C peptide (ng/mL) & $\begin{array}{l}8.88 \\
11.74) \quad(6.61-\end{array}$ & $\begin{array}{l}8.84 \\
10.92) \quad \text { (7.07- }\end{array}$ & $8.88 \quad$ (6.45- & 0.191 \\
\hline HOMA-IR & $4.56(2.39-7.99)$ & $4.11(2.23-7.42)$ & $5.27(2.72-9.22)$ & 0.359 \\
\hline $\begin{array}{l}\text { HbA1c (\%) } \\
\text { BUN (mmol/L) }\end{array}$ & $.00-7.65)$ & $6.70(6.00-7.65)$ & $6.80(6.03-7.75)$ & 0.730 \\
\hline $\begin{array}{l}\text { BUN (mmol/L) } \\
\text { Scr }(\mu \mathrm{mol} / \mathrm{L})\end{array}$ & $\begin{array}{l}6.00(5.00-7.15) \\
65(54-78)\end{array}$ & $\begin{array}{l}5.85(5.00-6.70) \\
62(52-76)\end{array}$ & $\begin{array}{l}6.20(5.20-7.70) \\
68(58-80)\end{array}$ & $\begin{array}{l}0.224 \\
0.441\end{array}$ \\
\hline $\begin{array}{l}\text { Serum úric } \\
(\mu \mathrm{mol} / \mathrm{L})\end{array}$ & $0.27(0.24-0.33)$ & $0.28(0.23-0.33)$ & $0.27(0.24-0.33)$ & 0.887 \\
\hline eGFR $\left(\mathrm{mL} \cdot \mathrm{min}^{-1} 1.73 \mathrm{~m}^{-}\right.$ & $121.15 \pm 30.98$ & $124.15 \pm 31.80$ & $116.74 \pm 29.41$ & 0.111 \\
\hline $\begin{array}{l}\text { TC }(\mathrm{mmol} / \mathrm{L}) \\
\text { TG }(\mathrm{mmol} / \mathrm{L}) \\
\text { LDL-C (mmol/L) } \\
\text { HDL-C (mmol/L) } \\
\text { UACR }(\mu \mathrm{g} / \mathrm{mg})\end{array}$ & $\begin{array}{l}5.26 \pm 1.18 \\
1.60(1.07-2.16) \\
3.00(2.40-3.40) \\
1.30(1.05-1.50) \\
14.42 \quad(6.04- \\
31.06) \quad\end{array}$ & $\begin{array}{l}5.07 \pm 0.99 \\
1.50(1.09-2.11) \\
2.90(2.40-3.30) \\
1.20(1.00-1.50) \\
11.29 \quad(4.59- \\
2.94)\end{array}$ & $\begin{array}{l}5.54 \pm 1.38 \\
1.63(1.01-2.28) \\
3.00(2.40-3.60) \\
1.30(1.10-1.60) \\
20.17 \quad(7.38-\end{array}$ & $\begin{array}{l}0.008 * \\
0.482 \\
0.094 \\
0.266 \\
0.651\end{array}$ \\
\hline CRP (mg/L) & $3.05(1.65-5.29)$ & $6.92(4.23-9.60)$ & (5.62- & $0.019 *$ \\
\hline $\begin{array}{l}\operatorname{IMT}(\mathrm{mm}) \\
\operatorname{HSP} 27(\mathrm{ng} / \mathrm{mL})\end{array}$ & $\begin{array}{l}1.03 \pm 0.42 \\
7.85 \\
10.92)\end{array}$ & $\begin{array}{l}0.78 \pm 0.19 \\
6.93(4.23-9.60)\end{array}$ & $\begin{array}{l}1.41 \pm 0.38 \\
8.80 \\
12.25)\end{array}$ & $\begin{array}{l}0.000^{*} \\
0.007 *\end{array}$ \\
\hline
\end{tabular}

$P<0.05\left(^{*}\right)$ 
Table 2. Univariate logistic analysis: predictors for carotid artery IMT

\begin{tabular}{|c|c|c|c|c|c|}
\hline & \multirow[t]{2}{*}{ B } & \multirow[t]{2}{*}{ OR } & \multicolumn{2}{|c|}{ 95\%CI } & \multirow[t]{2}{*}{$P$ value } \\
\hline & & & Lower & Upper & \\
\hline Sex & -0.441 & 0.643 & 0.354 & 1.169 & 0.148 \\
\hline Age & 0.067 & 1.069 & 1.035 & 1.105 & $0.000 *$ \\
\hline Onset age & 0.050 & 1.053 & 1.021 & 1.083 & $0.001 *$ \\
\hline Duration of diabetes & 0.019 & 1.019 & 0.978 & 1.062 & 0.370 \\
\hline Smoking & -0.178 & 0.837 & 0.420 & 1.667 & 0.613 \\
\hline Alcohol & 0.154 & 1.167 & 0.405 & 3.358 & 0.775 \\
\hline Lipid-lowering drugs & 0.391 & 1.478 & 0.819 & 2.669 & 0.195 \\
\hline CVD & -0.468 & 0.626 & 0.306 & 1.283 & 0.201 \\
\hline BMI & 0.040 & 1.041 & 0.950 & 1.141 & 0.390 \\
\hline WC & 0.010 & 1.011 & 0.977 & 1.045 & 0.542 \\
\hline WHR & 4.345 & 77.115 & 0.605 & 9837.212 & 0.079 \\
\hline SBP & 0.029 & 1.029 & 1.011 & 1.048 & $0.002 *$ \\
\hline DBP & 0.032 & 1.033 & 1.003 & 1.063 & $0.028 *$ \\
\hline FBG & $0.05 \overline{5}$ & 1.056 & 0.964 & 1.157 & 0.239 \\
\hline PBG & 0.009 & 1.009 & 0.961 & 1.059 & 0.716 \\
\hline HbA1c & 0.033 & 1.034 & 0.857 & 1.246 & 0.729 \\
\hline Fasting insulin & 0.005 & 1.005 & 0.994 & 1.016 & 0.403 \\
\hline $2 \mathrm{~h}$ insulin & 0.001 & 1.001 & 0.994 & 1.007 & 0.779 \\
\hline fasting C peptide & 0.056 & 1.058 & 0.847 & 1.322 & 0.620 \\
\hline $2 \mathrm{~h} \mathrm{C}$ peptide & 0.026 & 1.027 & 0.986 & 1.069 & 0.207 \\
\hline HOMA-IR & 0.014 & 1.014 & 0.984 & 1.044 & 0.368 \\
\hline BUN & 0.092 & 1.097 & 0.944 & 1.275 & 0.227 \\
\hline Scr & 0.004 & 1.004 & 0.993 & 1.016 & 0.448 \\
\hline Serum uric acid & 0.310 & 1.364 & 0.020 & 94.590 & 0.886 \\
\hline eGFR & -0.008 & 0.992 & 0.982 & 1.002 & 0.113 \\
\hline TC & 0.349 & 1.417 & 1.081 & 1.858 & $0.012 *$ \\
\hline TG & -0.076 & 0.927 & 0.750 & 1.146 & 0.485 \\
\hline LDL-C & 0.306 & 1.358 & 0.944 & 1.955 & 0.099 \\
\hline HDL-C & 0.409 & 1.505 & 0.733 & 3.089 & 0.265 \\
\hline CRP & 0.099 & 1.105 & 1.011 & 1.207 & $0.028 *$ \\
\hline UACR & 0.000 & 1.000 & 0.998 & 1.001 & 0.655 \\
\hline HSP27 & 0.084 & 1.088 & 1.021 & 1.159 & $0.009 *$ \\
\hline
\end{tabular}

Table 3. Multiple logistic regression analysis: independent predictors for carotid IMT in type 2 diabetes

\begin{tabular}{|c|c|c|c|c|c|}
\hline & \multirow[t]{2}{*}{ B } & \multirow[t]{2}{*}{ OR } & \multicolumn{2}{|c|}{ 95\%CI } & \multirow[t]{2}{*}{$P$ value } \\
\hline & & & Lower & Upper & \\
\hline Age & 0.059 & 1.061 & 1.006 & 1.119 & $0.028 *$ \\
\hline Onset age & 0.005 & 1.005 & 0.958 & 1.053 & 0.851 \\
\hline SBP & 0.004 & 1.004 & 0.977 & 1.031 & 0.795 \\
\hline DBP & 0.036 & 1.037 & 0.994 & 1.081 & 0.091 \\
\hline TC & 0.260 & 1.297 & 0.964 & 1.744 & 0.086 \\
\hline CRP & 0.051 & 1.052 & 0.963 & 1.149 & 0.259 \\
\hline HSP27 & 0.081 & 1.085 & 1.012 & 1.163 & $0.022 *$ \\
\hline
\end{tabular}


Table 4. Correlation between serum HSP27 and other parameters in type 2 diabetes

\begin{tabular}{lll}
\hline variable & & HSP27 \\
\cline { 2 - 3 } & $r$ & $P$ value \\
\hline Age & 0.074 & 0.313 \\
\hline Onset age & 0.091 & 0.217 \\
\hline Duration of diabetes & 0.000 & 0.999 \\
\hline BMI & 0.084 & 0.253 \\
\hline WC & -0.005 & 0.949 \\
\hline WHR & 0.023 & 0.753 \\
\hline SBP & 0.041 & 0.578 \\
\hline DBP & 0.018 & 0.811 \\
\hline FBG & 0.08 & 0.281 \\
\hline PBG & 0.005 & 0.945 \\
\hline HbA1c & 0.097 & 0.186 \\
\hline Fasting insulin & -0.142 & 0.054 \\
\hline 2 h insulin & -0.065 & 0.383 \\
Fasting C peptide & 0.033 & 0.659 \\
\hline 2 h C peptide & 0.072 & 0.332 \\
\hline HOMA-IR & -0.083 & 0.262 \\
\hline BUN & 0.170 & $0.020 *$ \\
Scr & 0.06 & 0.414 \\
\hline Serum uric acid & -0.075 & 0.312 \\
\hline eGFR & -0.018 & 0.812 \\
TC & 0.053 & 0.474 \\
TG & 0.035 & 0.637 \\
\hline LDL-C & 0.092 & 0.215 \\
\hline HDL-C & 0.070 & 0.341 \\
\hline UACR & 0.048 & 0.519 \\
\hline carotid IMT & 0.098 & 0.182 \\
\hline I Spearmans corren & 0.198 & $0.007 *$ \\
\hline
\end{tabular}

$r$ : Spearman's correlation coefficient. $P<0.05\left(^{*}\right)$

\section{Figures}




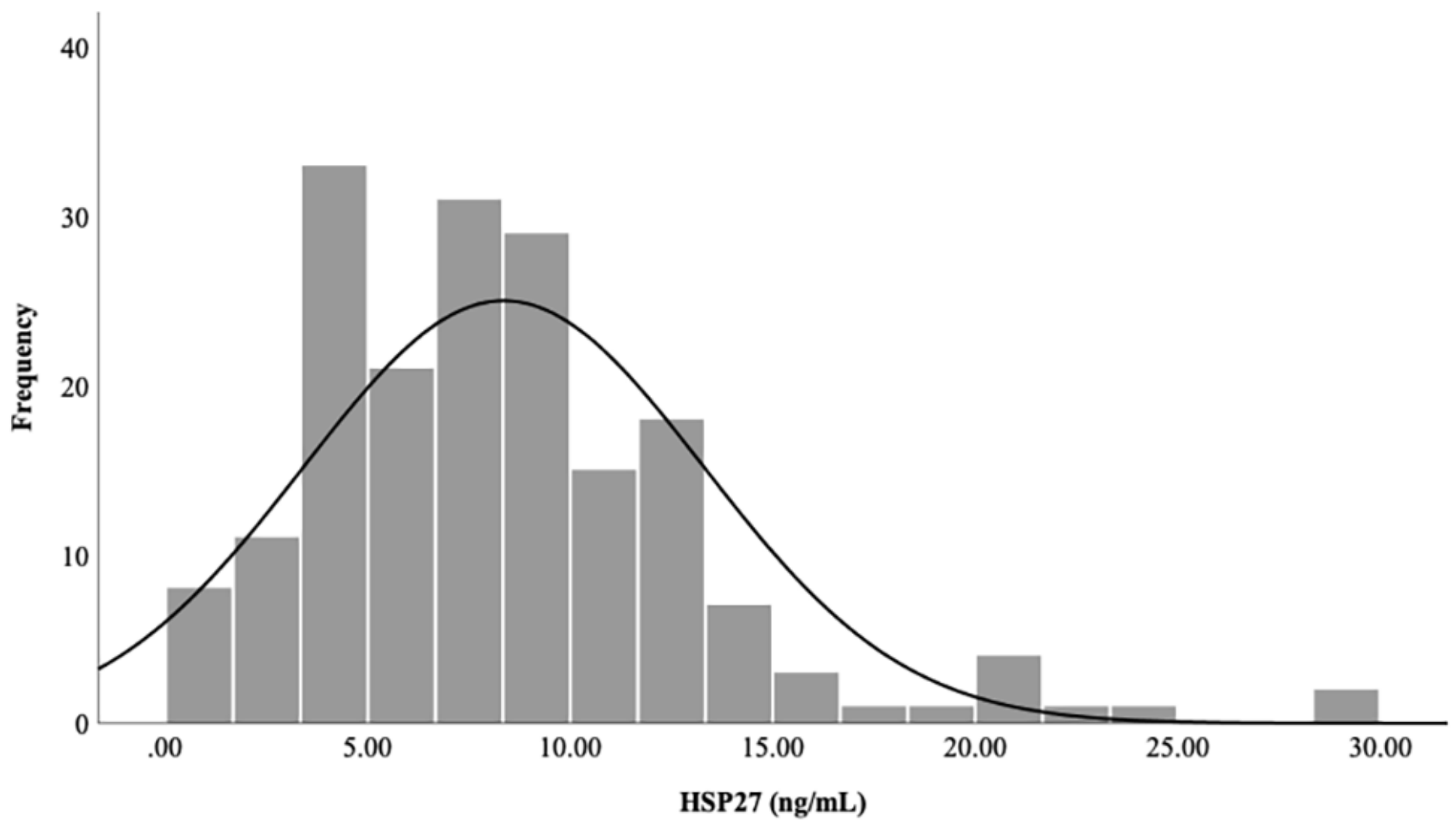

Figure 1

Distribution of serum HSP27 levels in the participants. 


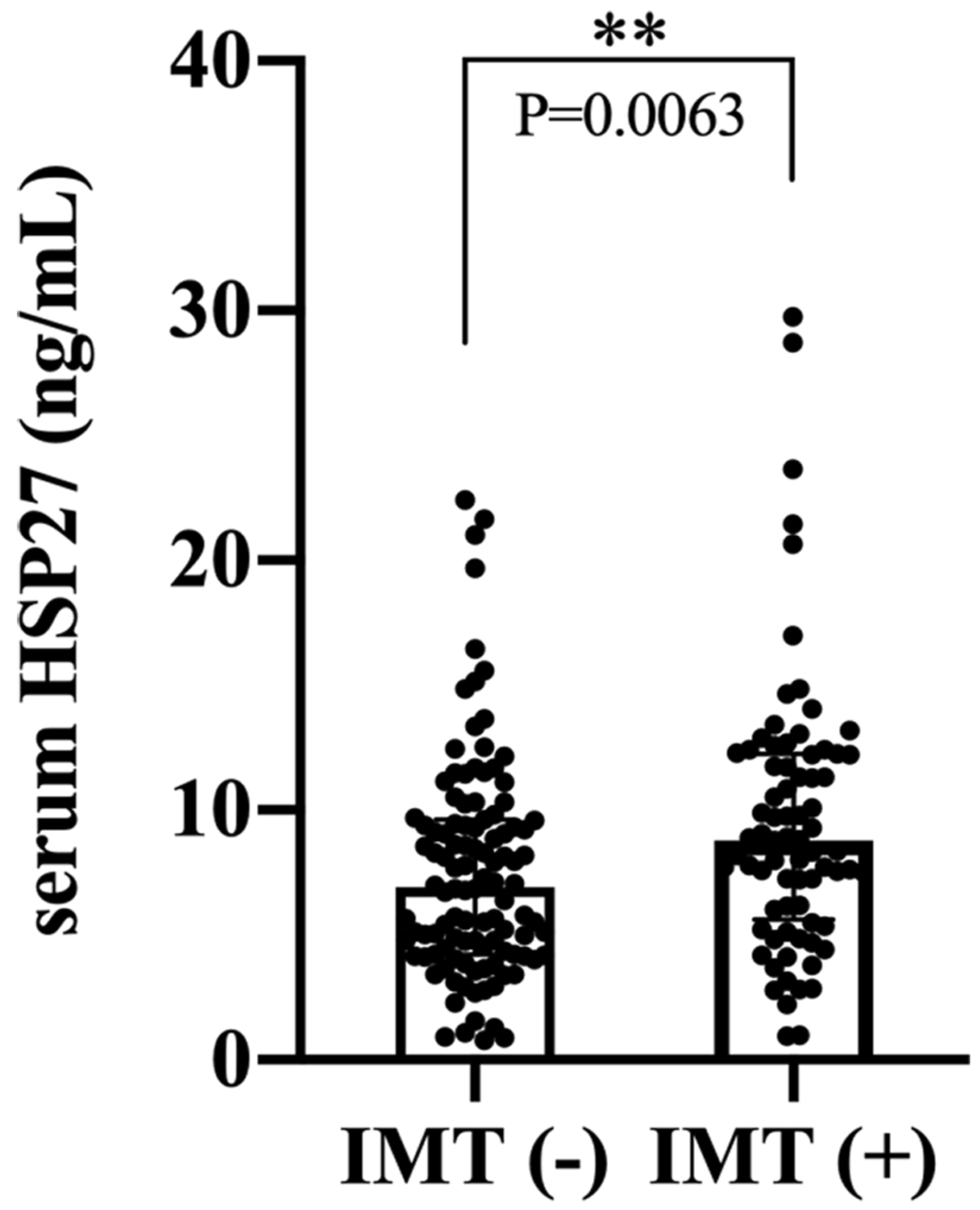

Figure 2

Serum HSP27 levels according to the values of IMT $1.0 \mathrm{~mm}$. Data are expressed as median (IQR) 


\section{ROC curve}

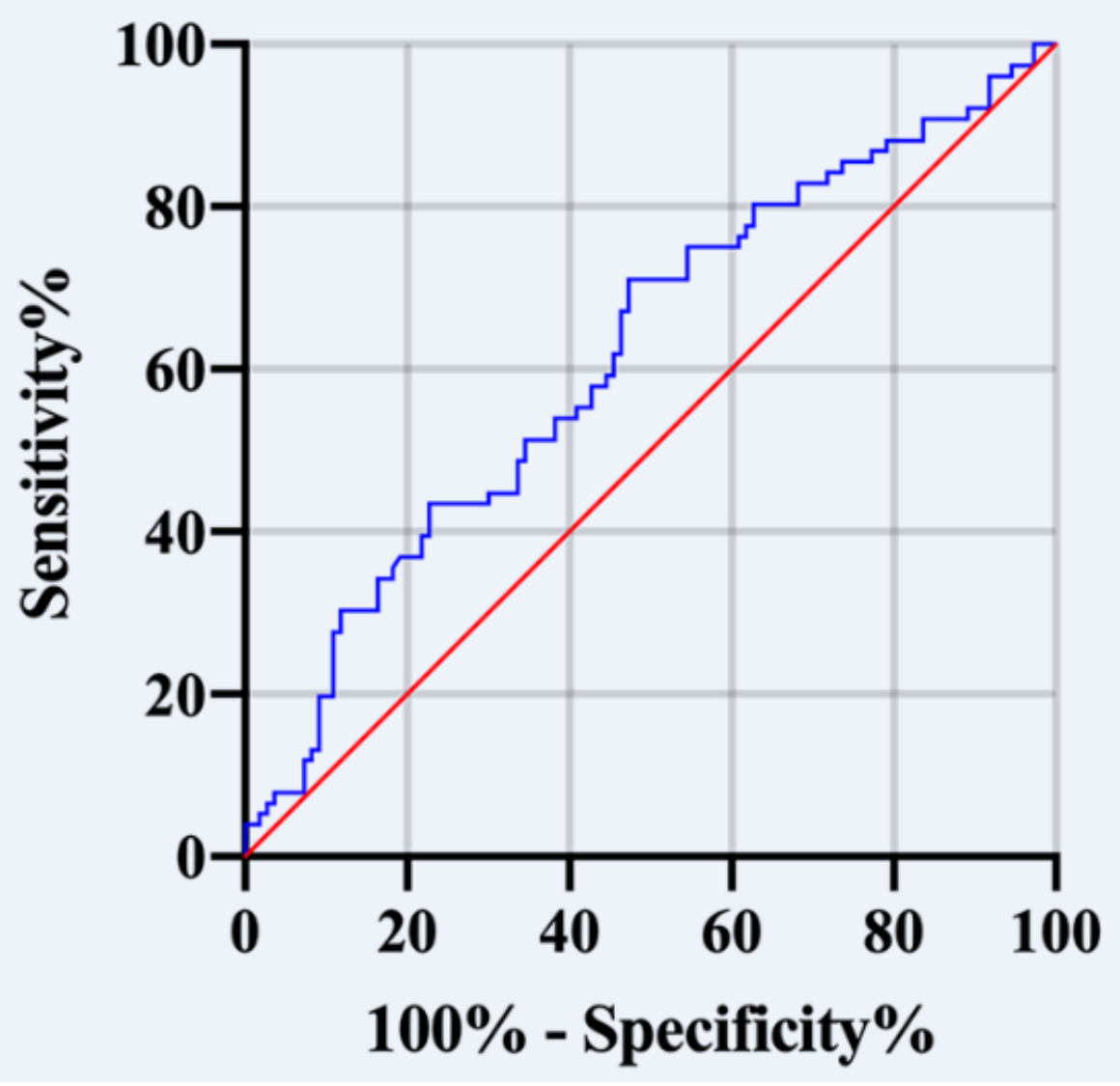

Sensitivity\%

Figure 3

The receiver operating characteristic (ROC) curve of HSP27 in patients with type 2 diabetes with $>1$ and $<1$ carotid IMT.The area under the curve was $0.72(95 \% \mathrm{Cl}=0.64-0.80, \mathrm{P}=0.0065)$

\section{Supplementary Files}

This is a list of supplementary files associated with this preprint. Click to download.

- Supplementarymaterial.docx 